\title{
Effect of soil tillage systems on chickpea yield and moisture of soil
}

\author{
Saeed Salehi ${ }^{1 *}$, Asad Rokhzadi ${ }^{2}$, Abdulwahab Abdolahi ${ }^{3}$, Khosro Mohammadi $^{4}$ and \\ Ghorban Nourmohammadi ${ }^{5}$ \\ ${ }^{1,2,4}$ Department of Agronomy, College of Agriculture, Sanandaj Branch, Islamic Azad University, Sanandaj, Iran \\ ${ }^{3}$ Dyland Agricultural Research Institute, Sararood branch, Agricultural Research, Education and Extension \\ Organization (AREEO), Kermanshah, Iran \\ ${ }^{5}$ Department of Agronomy, Science and Research Branch, Islamic Azad University, Tehran, Iran
}

\begin{abstract}
Sustainable agriculture is now considered as an important factor in the development of modern agriculture. Sustainable agriculture emphasizes the long-term yield stability with the least adverse impact on the environment. So tillage is a very important factor in agricultural economics. The aim of this study was to investigate the effect of tillage on chickpea yield in split strip plots based on a randomized complete block design with three replications in two growing years of 2014-2015 and 2015-2016 in Mahidasht located in Kermanshah. In this research, it was found that in the first year, the results of analysis of variance showed that the effect of tillage was significant only on grain yield at 5\% level. However, the effect of tillage on moisture content was not significant in the studied properties. In the second year of experiment, the tillage factor also had a significant effect on grain yield, biological yield, and moisture content at the depth of 0-20 cm at 5\% level, and it was significant on moisture content at the depth of 20-40 $\mathrm{cm}$ at second phase at 1\% level. Since the yield of the crop was lower in no tillage than in other cases, but the use of no tillage has caused that there is no place for agricultural equipment and machinery in the farm which caused density in soil. It should be noted that these machines and equipment are so expensive,this issue is very important in economic terms; therefore, the use of no tillage system is proposed.
\end{abstract}

KEY WORDS: NO TILLAGE, LOW TILLAGE, CONVENTIONAL TILLAGE, MOISTURE, CHICKPEA

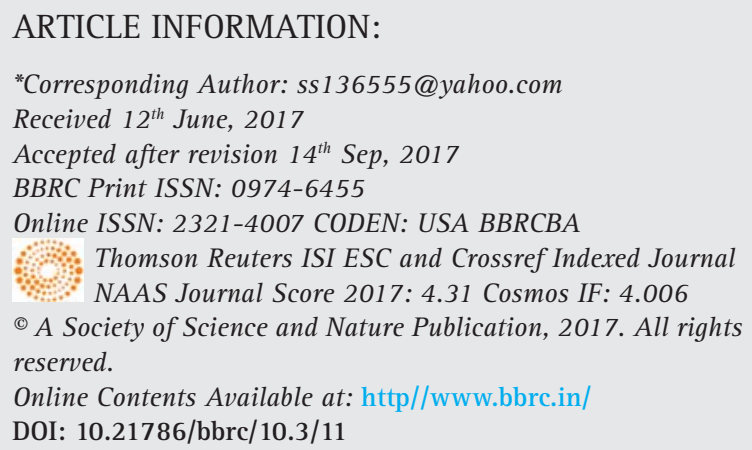




\section{INTRODUCTION}

In today's world, agriculture has faced the enormous challenges; soil erosion significantly reduces the yield of crops.Shortage of water and an increase in the price of fuel and fertilizer will increase production costs. Increasing demand for food as a result of the unprecedented growth of the population in recent decades has created a major challenge for researchers in the agricultural sector. The limitation of susceptible lands has caused that most of the strategies have not been led to increase yields per unit area Beans are one of the nutrient food for human and animal. In the agricultural systems of the world in rotation with other crops and nitrogen fixation, atmosphere in co-existence with bacteria provides the major part of the nitrogen needed for the next crops, (Sadeqipour, 2005, Goldani and Rezvani Moqaddam, 2007 and Afzali and Javaheri, 2013).

Soil tillage affects the important properties of soil such as temperature, moisture, and soil density. Thus, the correct use of tillage system can be the suitable strategy for plant growth and the optimal yield. The conventional tillage prepare artificial bed for the plant growth through the breakdown of soil impermeable layers, cleansing of soil surface from plant debris and discontinuing the life cycle of weeds, insects and diseases. But these systems not only require a lot of energy, but also, in the long run, these may destroy the physical properties of the soil and erode it. While water permeability in soil increases in low tillage systems due to increased organic matter and earthworm activity compared with conventional tillage system. Also, the use of low tillage systems and soil freeze will reduce the cost of energy consumption, reduce erosion and soil degradation, (Habibzadeh, 2006, Rasouli and Abbaspour, 2008 and Heidari, 2011).

Tillage operations are an inseparable part of the crop production cycle. The purpose of the tillage operation is the primary and main work on the soil, which is planned to reduce soil resistance, cover vegetation cover, and homogenizing its structure (Shafiei, 1992; Shafiei, 1995). According to Papendick and Parr (1997), due to organic matter depletion in dryland areas, the agricultural system will not be sustainable based on conventional tillage. Chen et al. (2006) concluded that the lack of moisture in the surface layers of the soil may cause the plant derives its moisture from the deeper layers of the soil that the essential nutrients are low. Thus, the plant suffers from nutrient stress; the sum of these factors reduces the plant size and existing photosynthetic reserves to fill the pods, and ultimately, it reduces the plant's yield.

Chassot et al. (2011) found that the surface of soil in no tillage is usually colder and wetter, and bulk densityis higher than conventional tillage. This has had an effect on the growth of chickpea root and the absorption of nutrients. Amini and Movahedi Naeini (2013) concluded that reducing the yield of products in no tillage system is directly affected by more mechanical soil resistance or lack of moisture and access to nutrients. By increasing the special surface of soils and thinning of clay soils, their cement property is strengthened and the mechanical strength of the soil increases. Even in wet conditions, the soil of the test site with a high surface has a high mechanical strength because, due to the fineness of the clay, the velocity of inflation and its equilibrium are very slowly absorbed by the waterwhich leads to a clogging between the soil components and mechanical strength. Long-term studies in the semi-arid region of the United States regarding field management by using conventional tillage, no tillage, and low tillage methods indicated that the weed control in no tillage system using herbicides only increased the wheat grain yield and the soil moisture. The yield of tillage is in the middle of the conventional and no tillage systems (Norwood and Currie, 1997).

\section{MATERIAL AND METHODS}

This research was carried out in dryland conditions in two separate experiments for chickpea in split plots (split plow split plots) based on a randomized complete block design with three replications in two growing years of 2014-2015 and 2015-2016 in Mahidshat which is located in Kermanshah. Three levels of tillage include: 1- conventional tillage (moldboard plowing), 2- low tillage (chisel plowing) and 3- no tillage. The experiment is carried out in a field that was cultivated the previous year. The area of each experimental plot $(5 \times 10 \mathrm{~m})$ is 50 square meters and each replicate includes 18 sub plots and the distance is 10 meters to allow the tractor to pass. The total number of plots in this experiment will be 108 . The amount of soil organic matter is measured before and after the project at a depth of $0-20 \mathrm{~cm}$. To determine the percentage of soil moisture content at flowering time and harvesting, samples were taken from the depth of 0-20 $\mathrm{cm}$ and $20-40 \mathrm{~cm}$. In the beginning of April, weeds are removed manually.

\section{RESULTS AND DISCUSSION}

Analysis of variance showed that the effect of tillage was significant on yield only at 5\% level. However, the effect of tillage on moisture content was not significant in any of the traits (Table 4-1).

\section{SECOND YEAR EXPERIMENT OF CHICKPEA}

In the second year of experiment, the effect of tillage was significant on grain yield, biological yield, moisture 


\begin{tabular}{|c|c|c|c|c|c|c|}
\hline \multicolumn{7}{|c|}{ Mean of squares } \\
\hline $\begin{array}{l}\text { Sources of } \\
\text { changes }\end{array}$ & df & $\begin{array}{l}\text { Weight of } \\
100 \text { seeds }\end{array}$ & $\begin{array}{l}\text { Number of pods } \\
\text { per square meter }\end{array}$ & $\begin{array}{c}\text { Number of } \\
\text { seeds per pods }\end{array}$ & $\begin{array}{l}\text { Grain } \\
\text { yield }\end{array}$ & $\begin{array}{l}\text { Biological } \\
\text { yield }\end{array}$ \\
\hline Replication & 2 & 1.00 & 22.67 & 7.25 & 21072 & 224437 \\
\hline Error 1 & 4 & 2.02 & 5.77 & 1.64 & 11207 & 35285 \\
\hline Tillage & 2 & 1.66 & 46.07 & 0.89 & $51799^{*}$ & 210352 \\
\hline Error 2 & 4 & 0.39 & 9.55 & 1.09 & 5820 & 232341 \\
\hline
\end{tabular}

Table 4.2. Analysis of variance of the first year to investigate the effects of moisture on chickpea

\begin{tabular}{|l|c|c|c|c|c|}
\hline \multicolumn{7}{|c|}{$\begin{array}{l}\text { Sources of } \\
\text { changes }\end{array}$} & df & $\begin{array}{c}\text { Moisture content at } \\
\text { the depth of 0-20 } \\
\text { cmphase 1 }\end{array}$ & $\begin{array}{c}\text { Moisture contentat } \\
\text { the depth of 20-40 } \\
\text { cmphase 1 }\end{array}$ & $\begin{array}{c}\text { Moisture content } \\
\text { at the depth of } \\
\mathbf{0 - 2 0} \text { cm phase 2 }\end{array}$ & $\begin{array}{c}\text { Moisture content } \\
\text { at the depth of } \\
\text { 20-40 cmphase 2 }\end{array}$ \\
\hline Replication & 2 & 3.21 & 19.17 & 8.42 & 55.68 \\
\hline Error 1 & 4 & 0.50 & 2.72 & 2.19 & 16.99 \\
\hline Tillage & 2 & 2.97 & 0.41 & 3.28 & 0.96 \\
\hline Error 2 & 4 & 1.36 & 0.91 & 1.51 & 1.66 \\
\hline $\begin{array}{l}\text { *and } \\
* \text { **indicate the significance level at 1 and 5, respectively. }\end{array}$ \\
\hline
\end{tabular}

content at the depth of 0-20 $\mathrm{cm}$ at 5\% level, it was also significant on moisture content at the depth of $20-40 \mathrm{~cm}$ at the second phase at $1 \%$ level.

\section{COMPARISON OF THE MEAN OF THE MAIN LEVELS OF THE FACTORS STUDIED IN CHICKPEA TWO-YEAR COMPOSITE ANALYSIS}

The result of the comparison of the average levels of tillage is shown in Table 4-5 and 4-6. As it can be seen, the tillage factor had only significant effect on 100 -seed weight and moisture content at the depth of 20-40 cm on the second phase; and it had no significant effect on other properties (Table 4-4, 4-5).
The tillage factor was only significant on the characteristics of 100 seed weight and leaf area index and was not significant on other characteristics. Mudak et al. (2001) in a seven-year trial on wheat yield reported that there is no significant difference between conventional tillage systems and no tillage. Simon et al., (2009) reported that soil tillage has an impact on most soil characteristics such as temperature, moisture distribution, and soil density, and the proper selection and implementation of an appropriate tillage system can provide a suitable bedding for the seed, and ultimately lead to optimal yield (Hemmat \&t Eskandari, 2006).

Although conventional tillage systems provide a good basis for plant growth by breaking the impermeable lay-

\begin{tabular}{|c|c|c|c|c|c|c|}
\hline \multicolumn{7}{|c|}{ Mean of squares } \\
\hline $\begin{array}{l}\text { Sources of } \\
\text { changes }\end{array}$ & df & $\begin{array}{l}\text { Weight of } \\
100 \text { seeds }\end{array}$ & $\begin{array}{l}\text { Number of pods } \\
\text { per square meter }\end{array}$ & $\begin{array}{c}\text { Number of } \\
\text { seeds per pods }\end{array}$ & Grain yield & $\begin{array}{c}\text { Biological } \\
\text { yield }\end{array}$ \\
\hline Replication & 2 & 0.97 & 238 & 12 & 21358 & 261282 \\
\hline Error 1 & 4 & 0.75 & 112 & 33 & 43026 & 69751 \\
\hline Tillage & 2 & 4.36 & 18 & 10 & 155361 & $724726^{*}$ \\
\hline Error 2 & 4 & 1.05 & 15 & 34 & 1384 & 91214 \\
\hline
\end{tabular}




\section{Weight of 100 seeds}
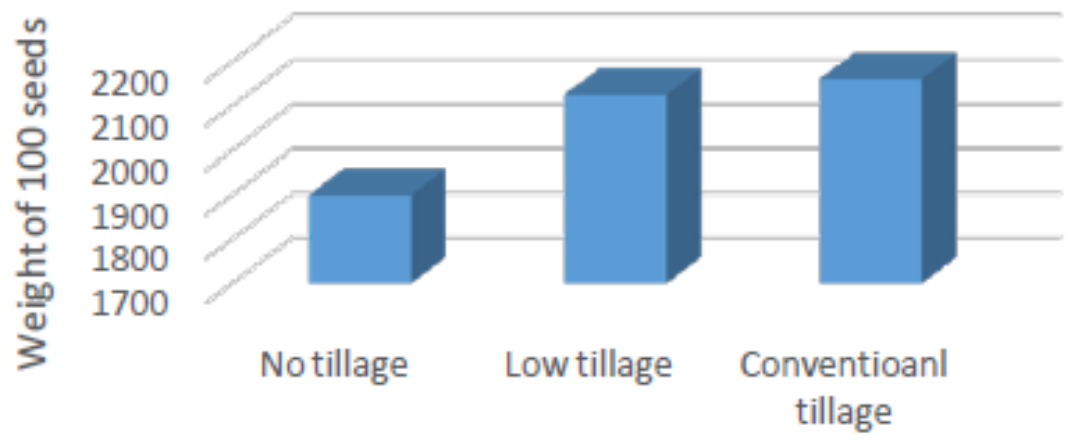

Tillage

FIGURE 1. Effect of tillage on grain weight

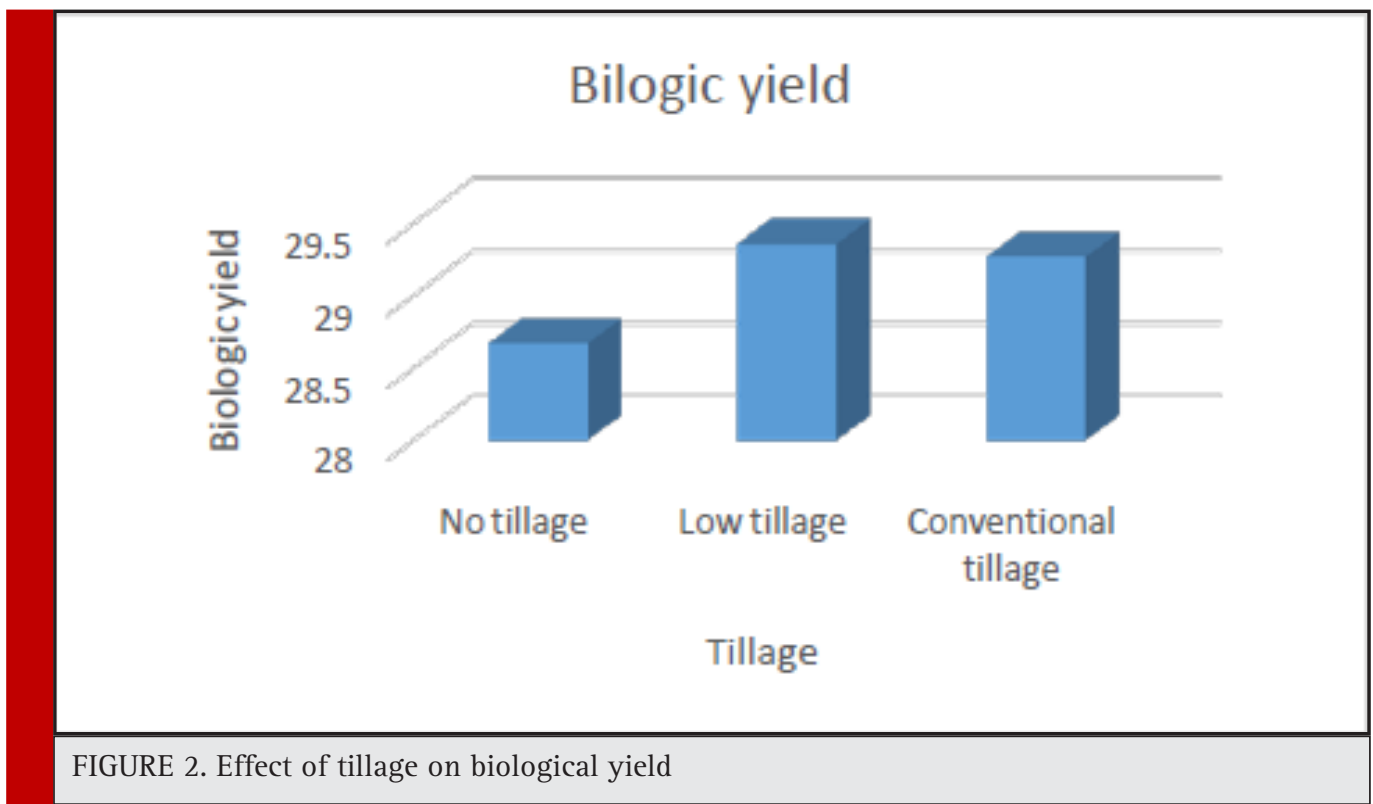

Table 4.4. Analysis of variance of the second year to investigate the effects of moisture on chickpea

\begin{tabular}{|c|c|c|c|c|c|}
\hline \multicolumn{6}{|c|}{ Mean of squares } \\
\hline $\begin{array}{l}\text { Sources of } \\
\text { changes }\end{array}$ & df & $\begin{array}{l}\text { Moisture content } \\
\text { at the depth of } \\
0-20 \mathrm{~cm} \text { phase } 1\end{array}$ & $\begin{array}{l}\text { Moisture content } \\
\text { at the depth of } \\
20-40 \mathrm{~cm} \text { phase } 1\end{array}$ & $\begin{array}{l}\text { Moisture content } \\
\text { at the depth of } \\
0-20 \mathrm{cmphase} 2\end{array}$ & $\begin{array}{l}\text { Moisture content } \\
\text { at the depth of } \\
20-40 \mathrm{cmphase} 2\end{array}$ \\
\hline Replication & 2 & 5.09 & 7.95 & 0.17 & 0.7 \\
\hline Error 1 & 4 & 0.81 & 5.75 & 0.38 & 0.57 \\
\hline Tillage & 2 & 6.35 & 4.30 & *1.32 & **5.13 \\
\hline Error 2 & 4 & 2.56 & 2.09 & 0.16 & 0.20 \\
\hline
\end{tabular}


Table 4.5. Comparison of the mean of tillage effect

\begin{tabular}{|l|c|c|c|c|c|c|}
\hline \multicolumn{2}{|c|}{ Characteristics } & Bumber of \\
Factor & & $\begin{array}{c}\text { Weight of } \\
100 \text { seeds }\end{array}$ & $\begin{array}{c}\text { Number of pods } \\
\text { per square meter }\end{array}$ & $\begin{array}{c}\text { Number } \\
\text { seeds per pods }\end{array}$ & Grain yield & Biologic yield \\
\hline \multirow{2}{*}{ Year } & First year & $10.16^{\mathrm{b}}$ & $19.63^{\mathrm{a}}$ & $27.23^{\mathrm{b}}$ & 469.76 & $1248^{\mathrm{b}}$ \\
\cline { 2 - 7 } & Second year & $30.93^{\mathrm{a}}$ & $25.41^{\mathrm{a}}$ & $30.97^{\mathrm{a}}$ & 829.06 & $2876^{\mathrm{a}}$ \\
\hline \multirow{3}{*}{ Tillage } & 0 & $20.70^{\mathrm{a}}$ & $21.53^{\mathrm{a}}$ & $28.67^{\mathrm{b}}$ & 0 & $1900^{\mathrm{b}}$ \\
\cline { 2 - 7 } & 1 & $20.73^{\mathrm{a}}$ & $22.06^{\mathrm{a}}$ & $29.36^{\mathrm{a}}$ & 1 & $2125^{\mathrm{ab}}$ \\
\cline { 2 - 7 } & 2 & $20.20^{\mathrm{a}}$ & $23.96^{\mathrm{a}}$ & $29.27^{\mathrm{a}}$ & 2 & $2161^{\mathrm{a}}$ \\
\hline
\end{tabular}

In each column and for each factor, the meanings that have at least one letter are not significantly different at the 5\% probability level. ": Tillage 0,1 and 2 respectively means non-tillage, low tillage, and conventional tillage.

Table 4.6. Comparison of the mean of moisture effect

\begin{tabular}{|c|c|c|c|c|c|}
\hline \multicolumn{6}{|c|}{ Characteristics } \\
\hline Factor & & $\begin{array}{l}\text { Moisture content at } \\
\text { the depth of } 0-20 \\
\text { cm phase } 1\end{array}$ & $\begin{array}{l}\text { Moisture content } \\
\text { at the depth of } \\
20-40 \mathrm{~cm} \text { phase } 1\end{array}$ & $\begin{array}{l}\text { Moisture contentat } \\
\text { the depth of } 0-20 \\
\text { cm phase } 2\end{array}$ & $\begin{array}{l}\text { Moisture content } \\
\text { at the depth of } \\
20-40 \mathrm{~cm} \text { phase } 2\end{array}$ \\
\hline \multirow{2}{*}{ Year } & First year & $13.90^{\mathrm{b}}$ & $26.96^{\mathrm{b}}$ & $11.72^{\mathrm{a}}$ & $15.34^{\mathrm{a}}$ \\
\hline & Second year & $15.51^{\mathrm{a}}$ & $30.53^{\mathrm{a}}$ & $9.23^{\mathrm{b}}$ & $12.20^{\mathrm{b}}$ \\
\hline \multirow{3}{*}{ Tillage } & 0 & $1508^{\mathrm{a}}$ & $28.43^{\mathrm{a}}$ & b 10.25 & $13.47^{\mathrm{a}}$ \\
\hline & 1 & $14.89^{\mathrm{a}}$ & a28.55 & $10.54^{\mathrm{a}}$ & $14.07^{\mathrm{a}}$ \\
\hline & 2 & $14.14^{\mathrm{a}}$ & a29.25 & a 10.64 & $13.76^{\mathrm{a}}$ \\
\hline
\end{tabular}

In each column and for each factor, the meanings that have at least one letter are not significantly different at the $5 \%$ probability level.

*: Tillage 0,1 and 2 respectively means non-tillage, low tillage, and conventional tillage.

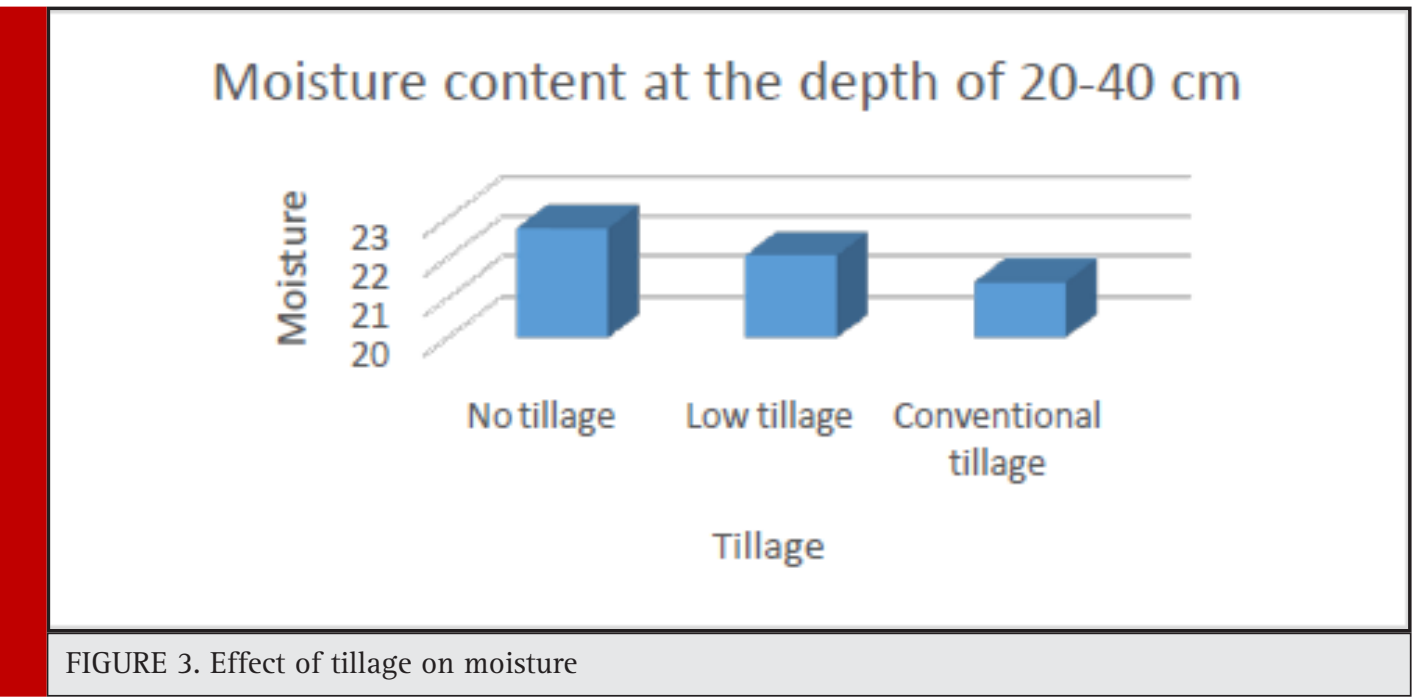

ers of soil and cutting the weed life cycle, pests and diseases (Mulumba $\mathrm{Ct}$ Lal, 2008), but these systems also require a lot of energy and In the long term, they destroy the physical properties of the soil (Sharma et al., 2011). Also, the use of low tillage and non-tillage systems reduces the costs of energy consumption, it decreases erosion and soil degradation (Katsviro 2002; Barzegar et al. 2004).
Astillage machines are heavy and large require 120 horsepower tractors to pull; these tractors cause density in the soil when traveling on the farm. So it's economical to use organic farming systems for ordinary farmers, and any farmer can use no tillage system.Since the yield in no-tillage compared to other system is lower, but there is no use of agricultural equipment and machines in no tillage system, this is so important in terms of economic. 


\section{REFERENCES}

Afzali, S.M. Javaheri A. (2013). The Effect of Soil Techniques on Soil Immersion Resistance, Technical Indices and Wheat yield. Journal of Agricultural Machinery, 3 (1): pp. 21-34.

Amini, S. Movahedi Naeini, S. A. R. (2013). Effects of Paper Mill Sludge Applicationon Physical Properties of an Illitic Loess Slowly Swelling Soil with High Specific SurfaceArea And Wheat Yield In a Temperate Climate. Journal of Agricultural Science. 1: 295-313.

Barzegar, AR. Hashemi, AM. Herbert, SJ. Asoodar, M. (2004). Interactive effects of tillage system and soil water content aggregate size distribution for seedbed preparation in Fluvisols southwest Iran. Soil and Tillage Research 78: 45-52.

Chassot, A. P. Stamp. W. Richner.(2011). Root distribution and morphology of maizeseedling as affected by tillage and fertilizer placement. Plant Soil 231, 123-135.13.

Chen, H.S. Liu, G.S. Yang Y.F.Ye, X.F. and Shi, Z. (2010). “Comprehensive evaluation of tobacco ecological suitability of Henan province based on GIS". Agri. Sci. China. 9: 583-592.

Goldani, M. Rezvani Moghadam, P. (2007). Effect of different moisture regimes and planting date on phenological characteristics and growth indices of three dry and blue chickpea cultivars in Mashhad. Journal of Agricultural Sciences and Natural Resources. 14 (1): 229-242.

Habibzadeh, Y. (2006). Effect of plant density on grain yield and morphophysiological characteristics of three genotypes of mung bean in Ahvaz condition. Journal of Agricultural Sciences of Iran, No. 81 (29): 66-78.

Heidari, A. (2011). Effect of soil tillage methods on soil physical characteristics and yield of wheat. Journal of Agricultural Science and Technology. Volume Fifty-Seven, No. 15. Pages 124-115.
Hemmat, A. Eskandari, I. (2006). Dryland winter wheat response to conservation tillage in a continuous cropping system in northwestern Iran. Soil and Tillage Research, 86, 99-109.

Katsvairo, T. Cox, WJ. Van, EH. (2002). Tillage and rotation effects on soil physical properties. Agronomy Journal 94: 299-304.

Mulumb, L. N. Lal, R. 2008. Mulching effects on selected soil physical properties. Soil and Tillage Research, 98, 106-111.

Norwood, C.A. Currie, R. S. (1997). Dry land corn vs. Grain sorghum in western kansas. Journal of production - agriculture (USA). (Jan-Mar 1997). V10 (1): 152-157.

Papendick, R.I. Parr, J.F. (1997). No-till farming: The way of the future for sustainable dryland agriculture. Ann. Arid Zone, 36 (3):193-208.

Rasouli, Sh. Abbaspour Gilandeh, Y.(2008). Investigating the effect of different soil tillage methods on soil physical properties. Proceedings of the 5th National Congress on Agricultural Machinery and Mechanization. Mashhad.

Shafiei, S. A.(1992). Principles of Agricultural Machinery, Vol. 1. Tehran University Press. No. 2135.

Shafiee, S. A. (1995). Agricultural machines. Tehran University Press. No. 757.

Sadeqipour, A. (2001). Plant production science, first part, beans (translation). Pezeshkiannejad Publications, Tehran.

Sharma, P. Abrol, V. Sharma, R.K. (2011). Impact of tillage and mulch management on economics, energy requirement and crop performance in maize-wheat rotation in rainfed subhumid inceptisols, India. European Journal of Agronomy, 34, 46-51.

Simon, T. Javurek, M. Mikanová, O. Vach, M. (2009). The influence of tillage systems on soil organic matter and soil hydrophobicity. Soil and Tillage Research, 105, 44-48. 